\title{
A laboratory characterisation of inorganic iodine emissions from the sea surface: dependence on oceanic variables and parameterisation for global modelling
}

\author{
S. M. MacDonald ${ }^{1}$, J. C. Gómez Martín ${ }^{1}$, R. Chance ${ }^{2}$, S. Warriner ${ }^{1}$, A. Saiz-Lopez ${ }^{3}$, L. J. Carpenter ${ }^{2}$, and \\ J. M. C. Plane ${ }^{1}$ \\ ${ }^{1}$ School of Chemistry, University of Leeds, Woodhouse Lane, Leeds, LS2 9JT, UK \\ ${ }^{2}$ Department of Chemistry, University of York, Heslington, York, YO10 5DD, UK \\ ${ }^{3}$ Atmospheric Chemistry and Climate Group, Institute of Physical Chemistry Rocasolano, CSIC, Madrid, Spain
}

Correspondence to: J. C. Gómez Martín (chmjgm@leeds.ac.uk)

Received: 30 October 2013 - Published in Atmos. Chem. Phys. Discuss.: 2 December 2013

Revised: 11 April 2014 - Accepted: 5 May 2014 - Published: 12 June 2014

\begin{abstract}
Reactive iodine compounds play a significant role in the atmospheric chemistry of the oceanic boundary layer by influencing the oxidising capacity through catalytically removing $\mathrm{O}_{3}$ and altering the $\mathrm{HO}_{\mathrm{x}}$ and $\mathrm{NO}_{\mathrm{x}}$ balance. The sea-to-air flux of iodine over the open ocean is therefore an important quantity in assessing these impacts on a global scale. This paper examines the effect of a number of relevant environmental parameters, including water temperature, salinity and organic compounds, on the magnitude of the $\mathrm{HOI}$ and $\mathrm{I}_{2}$ fluxes produced from the uptake of $\mathrm{O}_{3}$ and its reaction with iodide ions in aqueous solution. The results of these laboratory experiments and those reported previously (Carpenter et al., 2013), along with sea surface iodide concentrations measured or inferred from measurements of dissolved total iodine and iodate reported in the literature, were then used to produce parameterised expressions for the HOI and $\mathrm{I}_{2}$ fluxes as a function of wind speed, sea-surface temperature and $\mathrm{O}_{3}$. These expressions were used in the Tropospheric HAlogen chemistry MOdel (THAMO) to compare with MAX-DOAS measurements of iodine monoxide (IO) performed during the HaloCAST-P cruise in the eastern Pacific ocean (Mahajan et al., 2012). The modelled IO agrees reasonably with the field observations, although significant discrepancies are found during a period of low wind speeds $\left(<3 \mathrm{~m} \mathrm{~s}^{-1}\right)$, when the model overpredicts IO by up to a factor of 3 . The inorganic iodine flux contributions to IO are found to be comparable to, or even greater than, the contribution of organo-iodine compounds and therefore its inclusion in at-
\end{abstract}

mospheric models is important to improve predictions of the influence of halogen chemistry in the marine boundary layer.

\section{Introduction}

Reactive iodine compounds play an important role in the chemistry of the marine boundary layer (MBL) through their influence on ozone depletion and the oxidising capacity via repartitioning of $\mathrm{HO}_{\mathrm{x}}$ and $\mathrm{NO}_{\mathrm{x}}$ (Saiz-Lopez et al., 2012). Iodine oxides also form new particles spontaneously in coastal (O'Dowd et al., 2002) and polar regions (Atkinson et al., 2012), potentially leading to the production of cloud condensation nuclei. In coastal regions, emissions of molecular iodine and to a lesser extent of halocarbons from macroalgae are found to be the dominant source of reactive iodine to the MBL (O'Dowd et al., 2002). The source of reactive iodine and particles observed over the Antarctic sea ice remains to be determined (Atkinson et al., 2012).

Recent ground-, ship- and aircraft-based measurements have found that IO is ubiquitous over the open oceans, with MBL-averaged mixing ratios of around $0.5 \mathrm{pptv}$, and surface mixing ratios of up to 3 pptv (Allan et al., 2000; Mahajan et al., 2010, 2012; Dix et al., 2013; Gómez Martín et al., 2013; Großmann et al., 2013). Modelling studies have shown that these levels of IO cannot be sustained by the measured iodocarbon fluxes and that an additional source of reactive iodine from the open ocean, equivalent to $>50 \%$ of 
the total surface iodine emission, is required to match the observations (Jones et al., 2010; Mahajan et al., 2010). Correlation studies of ground- and ship-based IO and reactive iodine $\left(\mathrm{IO}_{\mathrm{x}}=\mathrm{IO}+\mathrm{I}\right)$ measurements with oceanic variables have shown that there is a negative correlation with Chl $a$ and CDOM (colored dissolved organic matter), suggesting that the additional iodine production over the oceans is not biological and could be inhibited by the presence of increased biological activity or organic matter (Mahajan et al., 2012; Gómez Martín et al., 2013; Großmann et al., 2013). This provides evidence for the widespread abiotic iodine source proposed by Garland and Curtis (1981): the sea surface oxidation of $\mathrm{I}^{-}$by $\mathrm{O}_{3}$ to yield $\mathrm{HOI}$ and $\mathrm{I}_{2}$, which are then either released directly to the atmosphere or react with dissolved organic matter (Garland and Curtis, 1981; Martino et al., 2009; Carpenter et al., 2013). In addition, the correlation analysis showed significant correlations of $\mathrm{IO}_{\mathrm{x}}$ with sea surface temperature (SST) and salinity (SSS), which suggests that this abiotic mechanism will be influenced by oceanic variables.

Previously we provided the first experimental evidence that both $\mathrm{I}_{2}$ and $\mathrm{HOI}$ are emitted from the reaction of $\mathrm{I}^{-}+\mathrm{O}_{3}$ in the interfacial layer, and that these emissions can account for the missing source of reactive iodine over the tropical Atlantic Ocean (Carpenter et al., 2013). Very recently the first measurements of $I_{2}$ at a remote marine site (Cape Verde) have been reported (Lawler et al., 2014), with night time mixing ratios of up to $1.7 \mathrm{pptv}$. These mixing ratios are not enough to sustain the levels of IO observed at Cape Verde (Mahajan et al., 2010), which concurs with our laboratory observations of HOI being the major species emitted from the ocean surface. In this paper we investigate the dependence of the flux of inorganic iodine on relevant environmental parameters such as water temperature, salinity and the presence of organics. From these results and those previously reported (Carpenter et al., 2013), and using a kinetic model of the sea-air interface, parameterised expressions for the flux of both $\mathrm{HOI}$ and $\mathrm{I}_{2}$ are derived. These expressions are then used in a 1-D atmospheric chemistry model for comparison with the field observations of reactive iodine species ( $\mathrm{IO}$ and $\mathrm{IO}_{\mathrm{x}}$ ) recorded under a wide range of oceanic conditions during the HaloCAST-P cruise in the eastern Pacific Ocean (Mahajan et al., 2012).

\section{Experimental}

The experimental setup used has been described in detail elsewhere (Carpenter et al., 2013, Supplement) and involves detection of $\mathrm{I}_{2}$ and HOI released from an ozonised iodide solution through selective photolysis, reaction of the resulting I radicals with an excess of $\mathrm{O}_{3}$ to form iodine oxide particles (IOPs) (Saunders et al., 2010), and subsequent detection of these particles using a nano-differential mobility analyser (nano-DMA) (Fig. 1). For the selective photolysis, two methods were used: a xenon or tungsten lamp along with suitable

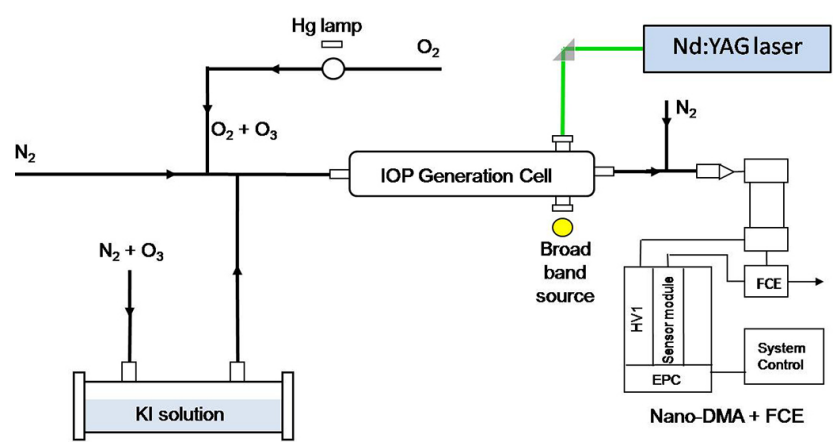

Figure 1. Experimental setup showing the two different types of light sources (W/Xe lamp or Nd:YAG laser) used to photolyse and distinguish between $\mathrm{I}_{2}$ and $\mathrm{HOI}$.

$10 \mathrm{~nm}$ bandwidth interference filters, or photolysis at either $532 \mathrm{~nm}\left(\mathrm{I}_{2}\right)$ (Saiz-Lopez et al., 2004) or $355 \mathrm{~nm}$ (HOI) (Rowley et al., 1999) using a frequency doubled or tripled Nd:YAG laser (Continuum Surelite). The laser energy was continuously monitored using a powermeter (Molectron Powermax $500 \mathrm{~A}$ ), so that the data could be normalised to the same pulse energy. The tungsten lamp showed high sensitivity for $I_{2}$ but did not allow measurements of HOI. The xenon lamp was used for measurements of $\mathrm{HOI}$ - however, the sensitivity and selectivity using this light source was poor. The laser was employed to measure $\mathrm{I}_{2}$ and $\mathrm{HOI}$ independently and enabled high sensitivity for both species and back-to-back operation. The experimental setup was calibrated using a known flow of $\mathrm{I}_{2}$ vapour, produced by passing $\mathrm{N}_{2}$ through a glass trap containing solid $\mathrm{I}_{2}$ (Sigma Aldrich) in equilibrium with its vapour phase, for each of the light sources used. At the low $\mathrm{I}_{2}$ concentrations and photolysis rates of the experiments the IOP mass is a linear function of the $\mathrm{I}_{2}$ concentration and accurate calibration coefficients can be obtained, typically with an uncertainty of $\sim 8 \%$ encompassing the uncertainty of the iodine vapour pressure (Baxter et al., 1907) and the statistical uncertainty from the linear regression. The detection limits using laser photolysis are typically $\sim 2$ pptv for $I_{2}$ and $\sim 50$ pptv for HOI. In the $\mathrm{I}^{-}+\mathrm{O}_{3}$ experiments, the requirement to work at close to environmentally relevant concentrations of iodide and $\mathrm{O}_{3}$ (within a factor of 10) results in a range of IOP numbers close to the detection limit of the particle counter, which may reduce the precision of the measurements.

For the temperature dependence experiments a doublewalled glass cell was used to allow cooled water to be flowed around the iodide solution. Temperatures ranging from 276 to $298 \mathrm{~K}$ were monitored using a thermocouple inserted into the solution in the cell. The iodide solutions were made up to the relevant concentrations using potassium iodide (KI) (Alfa Aesar, A12704) dissolved in deionised water buffered to $\mathrm{pH} 8$ using $0.1 \mathrm{M}$ sodium phosphate (Sigma Aldrich). For the salinity dependence experiments, reagent grade $\mathrm{NaCl}$ (Fisher Scientific S/3160/53) was added to $1 \times 10^{-6} \mathrm{M} \mathrm{KI}$ 
solutions to give concentrations ranging from 0 to $0.5 \mathrm{M} \mathrm{Cl}^{-}$. To estimate the trace iodide present as a potential contaminant in the $\mathrm{NaCl}, 0.104 \mathrm{M}$ solutions in water (LC-MS Chromasolv - Fluka 39253) containing variable concentrations of $\mathrm{KI}$ (concentrations ranging from 0 to $99.4 \times 10^{-9} \mathrm{M}$, acquisitions performed in duplicate) were prepared and directly infused into a Bruker MaXis Impact Q-TOF mass spectrometer in negative electrospray ionisation mode. Full profile data were acquired with a $1 \mathrm{~Hz}$ acquisition rate for $3 \mathrm{~min}-$ utes. The spectra were summed over the length of the acquisition and the relative intensity of the iodide peak (theoretical $m / z$ 126.90522) relative to the cluster ion $(\mathrm{NaCl})_{2} \mathrm{Cl}^{-}$(theoretical $m / z 150.886645)$ was calculated. The spectra were calibrated using the $(\mathrm{NaCl})_{n} \mathrm{Cl}^{-}$clusters as internal references. The observed mass of the iodide ion peak was within $3 \mathrm{ppm}$ of the theoretical value in all cases.

For the experiments involving organics, in the case of humic acid (Sigma Aldrich) a small amount was added to a prepared iodide solution which was then stirred overnight and any remaining solid filtered off. The concentration of humic acid was determined by UV/Vis spectroscopy to be around $2 \mathrm{mg} \mathrm{dm}^{-3}$, using a specific absorbance of $5 \mathrm{~L} \mathrm{mg}^{-1} \mathrm{~m}^{-1}$ at $254 \mathrm{~nm}$ (Weishaar et al., 2003). Sodium dodecyl sulfate (SDS, Sigma Aldrich) was added to a $1 \times 10^{-7} \mathrm{M}$ KI solution at a concentration of $6.2 \times 10^{-3} \mathrm{M}$. Finally, for the experiments involving phenol, $1 \times 10^{-7} \mathrm{M} \mathrm{KI}$ solutions containing phenol (Acros Organics) at concentrations ranging from $1 \times 10^{-8}$ to $1 \times 10^{-3} \mathrm{M}$ were prepared.

\section{Results}

\subsection{Salinity}

The results of the salinity dependence experiments, using pH 8 buffered iodide solutions, are shown in Fig. 2. There is a clear increase in the $\mathrm{I}_{2}$ flux with increasing salinity, with the flux around 2.5 times higher at $0.5 \mathrm{M} \mathrm{NaCl}$ (roughly equivalent to a salinity of $32 \%$ ) compared to a solution containing no chloride.

The quantitative mass spectrometric analysis of the $\mathrm{NaCl}$ employed in these experiments allows us to rule out a significant contribution of an iodide impurity to the increasing $\mathrm{I}_{2}$ flux. The relative intensity of the iodide mass peak observed in the $0.104 \mathrm{M} \mathrm{NaCl}$ solution was less than that observed in the sample spiked with $9.9 \times 10^{-9} \mathrm{M} \mathrm{KI}$. Therefore, the $0.5 \mathrm{M} \mathrm{NaCl}$ solution contained less than $50 \times 10^{-9} \mathrm{M} \mathrm{I}^{-}$impurity, a factor of 20 smaller than the $1 \times 10^{-6} \mathrm{M} \mathrm{I}^{-}$concentration employed in the salinity experiments. The equivalent in terms of $\mathrm{I}_{2}$ flux would be $<6 \times 10^{8}$ molecule $\mathrm{cm}^{-2} \mathrm{~s}^{-1}$ at $0.5 \mathrm{M} \mathrm{NaCl}$, i.e. well within experimental error $\left( \pm 4 \times 10^{9}\right.$ molec. $\left.\mathrm{cm}^{-2} \mathrm{~s}^{-1}\right)$.

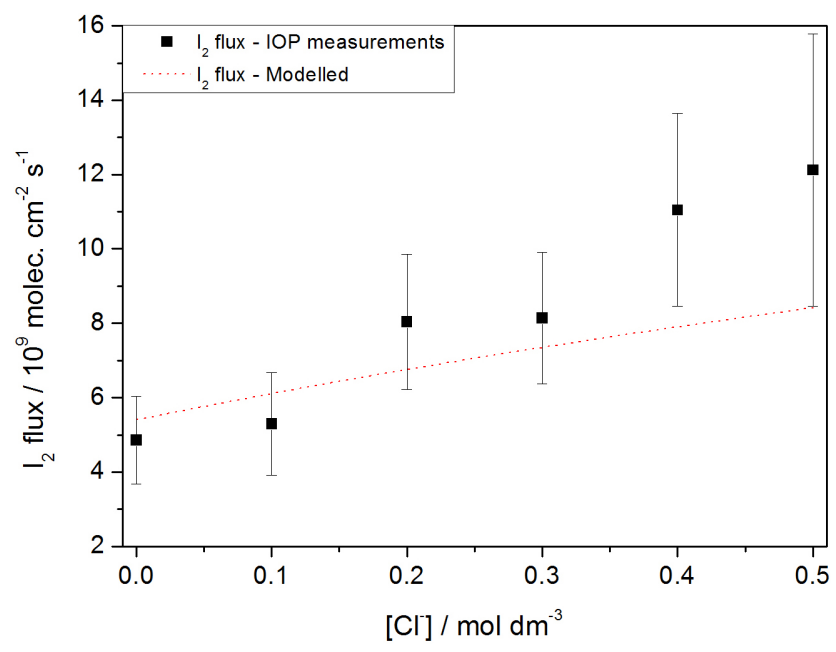

Figure 2. $\mathrm{I}_{2}$ flux from solution as a function of chloride concentration, showing a clear increase in both model (red dashed line) and measurements (black squares).

\subsection{Organics}

A number of organic species were added to the KI aqueous solutions to investigate the effect of these compounds on the resulting $\mathrm{I}_{2}$ flux. The first of these was humic acid (Sigma Aldrich), which was used as a proxy for dissolved organic matter found in seawater. Humic acid consists of a mixture of organic compounds formed from the degradation of organic matter. The $\mathrm{I}_{2}$ flux was unaffected by the addition of relevant seawater concentrations $\left(\sim 2 \mathrm{mg} \mathrm{dm}^{-3}\right)$ of humic acid.

A further organic compound investigated was sodium dodecyl sulfate (SDS), which is a surfactant compound commonly found in a number of detergents and present at around $10 \mu \mathrm{g} \mathrm{dm}^{-3}$ in seawater (Ćosović et al., 1985). Surfactants are known to cause a reduction in the sea-air transfer of a number of atmospheric species by forming a barrier to emission. SDS was added to a $1 \times 10^{-7} \mathrm{M}$ KI solution at sufficient concentration to form a monolayer at the solution surface $\left(6.2 \times 10^{-3} \mathrm{M}\right)$ (Hore et al., 2005). However, this amount of SDS was found to have no observable effect on the resulting IOP mass.

Previous studies have shown that phenol can have a significant effect on the $\mathrm{I}_{2}$ flux in the $\mathrm{I}^{-}+\mathrm{O}_{3}$ reaction (Hayase et al., 2010). It is commonly found in seawater, mainly from anthropogenic sources at concentrations of around $1 \times 10^{-8}$ to $1 \times 10^{-7} \mathrm{M}$. In our experiments, using realistic seawater concentrations of both iodide $\left(1 \times 10^{-7} \mathrm{M}\right)$ and phenol $\left(1 \times 10^{-8}-1 \times 10^{-7} \mathrm{M}\right)$ there was no difference observed in the measured $\mathrm{I}_{2}$ flux within the $50 \%$ uncertainty of the observed IOP mass. The phenol concentration had to be increased up to $1 \times 10^{-3} \mathrm{M}$ before a $50 \%$ decrease in the $\mathrm{I}_{2}$ flux was observed. 


\subsection{Temperature dependence}

The temperature dependence of $\mathrm{HOI}$ and $\mathrm{I}_{2}$ emissions from ozonised iodide solutions was investigated using both broadband light sources (xenon and tungsten lamps) and the $\mathrm{Nd}$ :YAG laser source to photolyse $\mathrm{I}_{2}$ and $\mathrm{HOI}$ and produce detectable IOPs. The differing detection limits of the various systems necessitated different concentrations of $\mathrm{I}^{-}$or $\mathrm{O}_{3}$ to be able to measure both $\mathrm{I}_{2}$ and HOI. The iodide concentration used in these experiments ranged from $1 \times 10^{-6}-5 \times 10^{-6} \mathrm{M}$ and the ozone ranged from 222 to $3600 \mathrm{ppbv}$. In order to account for changes in the observed $\mathrm{I}_{2}$ and HOI fluxes caused by different ozone and iodide concentrations, as well as for $\mathrm{pH}$ variation with temperature, the $\mathrm{HOI}$ and $\mathrm{I}_{2}$ fluxes were normalised by dividing through by the $\mathrm{O}_{3}, \mathrm{I}^{-}$and $\mathrm{H}^{+}$concentrations according to the individual experiments (we have shown previously (Carpenter et al., 2013) that the HOI and $\mathrm{I}_{2}$ fluxes are proportional to the concentrations of these species over the ranges employed here). The Arrhenius plots for the resulting normalised fluxes are shown in Fig. 3, along with the $95 \%$ confidence limits for the activation energies. The resulting activation energy for the $\mathrm{I}_{2}$ flux is $-7 \pm 18 \mathrm{~kJ} \mathrm{~mol}^{-1}$, and $17 \pm 50 \mathrm{~kJ} \mathrm{~mol}^{-1}$ for the HOI flux (using conservative $95 \%$ confidence limits rather than parameter errors). Even though the requirement of working under environmentally relevant conditions implies $\mathrm{I}_{2}$ and HOI concentrations not far from the detection limit, the reproducibility of the room temperature data shows that the precision of the detection method is not a matter of concern. The major problem is the reproducibility of conditions of the experiment itself, i.e. in the cell containing the KI solution, and in particular in the experiments at low temperature, as shown by the error bars in Fig. 3. A possible explanation is uptake and release of iodine species on the inner walls and the outlet of the temperature stabilised cell.

\section{Discussion}

\subsection{Salinity}

There do not appear to have been any previous studies investigating the effect of chloride concentration on the rate of the $\mathrm{I}^{-}+\mathrm{O}_{3}$ reaction. The kinetic interfacial model described in Carpenter et al. (2013) satisfactorily predicts the observed positive dependence of the $\mathrm{I}_{2}$ flux on the $\mathrm{Cl}^{-}$concentration (Fig. 2). The reason for this increase is due to conversion of a small amount of $\mathrm{HOI}$ into $\mathrm{I}_{2}$ via $\mathrm{ICl}$ :

$$
\begin{aligned}
& \mathrm{Cl}^{-}+\mathrm{HOI}+\mathrm{H}^{+} \rightleftarrows \mathrm{ICl}+\mathrm{H}_{2} \mathrm{O} \\
& \mathrm{ICl}+\mathrm{I}^{-} \rightleftarrows \mathrm{I}_{2} \mathrm{Cl}^{-} \\
& \mathrm{I}_{2} \mathrm{Cl}^{-} \rightleftarrows \mathrm{I}_{2}+\mathrm{Cl}^{-} .
\end{aligned}
$$

Note that this has very little effect on the HOI emission due to its great excess in the interfacial layer (Carpenter et al.,

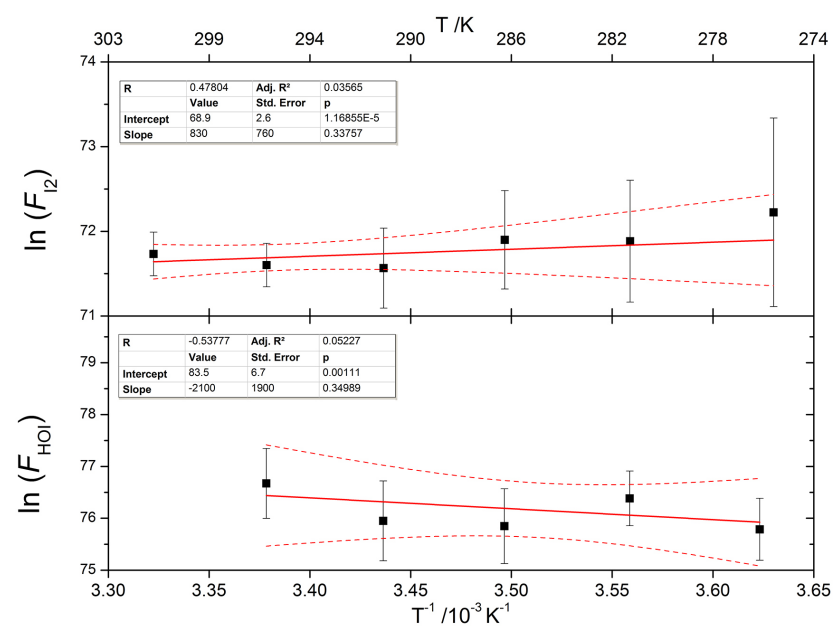

Figure 3. Arrhenius plots for $\mathrm{I}_{2}$ and HOI produced from the combined data using each light source normalised for $\left[\mathrm{O}_{3}\right],\left[\mathrm{I}^{-}\right]$and $\left[\mathrm{H}^{+}\right]$. Dashed lines indicate the $95 \%$ confidence limits of the linear fits.

2013). As shown in Fig. 2, the observations exhibit a slightly larger chloride dependence, with a greater $\mathrm{I}_{2}$ flux observed at $0.5 \mathrm{M} \mathrm{Cl}^{-}$than the model predicts. This probably indicates the additional effect of the surface enhancement of $\mathrm{I}^{-}$ions, which has been reported in a number of previous experimental and theoretical studies (Ghosal et al., 2005; Caleman et al., 2011; Gladich et al., 2011). In these studies $\mathrm{I}^{-}$is shown to have a greater preference for the surface of an aqueous solution than $\mathrm{Br}^{-}$or $\mathrm{Cl}^{-}$, which has been explained by the more polarisable $\mathrm{I}^{-}$anions having a lower excess surface free energy compared to either $\mathrm{Br}^{-}$or $\mathrm{Cl}^{-}$(Jungwirth and Tobias, 2005; Gladich et al., 2011).

Although there is a clear dependence of the $I_{2}$ flux on the $\mathrm{Cl}^{-}$concentration, in seawater this effect is unlikely to be important due to the very small changes in SSS. Over the range of SSS commonly observed in the oceans (32-37\%o), the resulting change in the $\mathrm{I}_{2}$ flux based on the experimental results would be only around $1 \%$.

\subsection{Organics}

The results of our humic acid experiments are in agreement with those of Hayase et al. (2012) who also found no effect on $\mathrm{I}_{2}$ emission from the addition of humic acid. However, they did observe an increase in $\mathrm{I}_{2}$ emission when fulvic acid was added which they attributed to greater efficiency of proton supply from the carboxylic acid group compared to water. Hayase et al. (2010) investigated the effect that certain organic compounds have on the $\mathrm{I}^{-}+\mathrm{O}_{3}$ reaction. They found that phenol and other species containing the phenol functional group had a marked effect on the iodine emitted to the gas phase. Working at concentrations which were significantly higher than ambient levels $\left(5 \times 10^{-3} \mathrm{M} \mathrm{NaI}\right.$ and $1 \times 10^{-3} \mathrm{M}$ phenol, at $\mathrm{pH} 6$, so most phenol was phenolate), 
the $\mathrm{I}_{2}$ and IO produced was around half that of a pure $\mathrm{NaI}$ solution. This was attributed to the fast reaction of the phenolate ion with $\mathrm{O}_{3}\left(1.4 \times 10^{9} \mathrm{M}^{-1} \mathrm{~s}^{-1}\right)$, which competes with that of $\mathrm{I}^{-}$. Our results agree with that earlier study. However, the concentrations of phenol are orders of magnitude higher than that found in seawater, so phenolic compounds should not play an important role in regulating the emission of $\mathrm{I}_{2}$ from the ocean.

Reeser and Donaldson (2011) showed that addition of an aqueous monolayer of octanol to ozonised KI solutions resulted in a decrease in the observed $\mathrm{I}_{2}$ emission by a factor of $\sim 2$, due to changes in gas-solution partitioning. Rouviere and Ammann (2010) found that certain surfactant species form a barrier to ozone uptake from an iodide solution, which implies inhibition of the release of iodine to the gas phase. Their work suggests, however, that chain lengths of $>\mathrm{C} 15$ may be necessary for a significant reduction in the $\mathrm{O}_{3}$ loss. This is most likely due to the structure of the monolayer formed and how densely the monomers are packed. SDS has a carbon chain length of $\mathrm{C} 11$ which may explain the lack of an inhibiting effect observed in our experiments. Recently, Shaw and Carpenter (2013) have also reported a suppression of a factor of $\sim 2$ of the $\mathrm{I}_{2}$ emission when dissolved organic carbon (DOC) of coastal seawater origin is added to ozonised iodide solutions, under conditions of $\mathrm{O}_{3}$ reactivity with iodide and DOC representative of the open ocean, which they have also attributed to a surface physical effect.

\subsection{Temperature}

Magi et al. (1997) used the droplet train technique to measure the disappearance of $\mathrm{O}_{3}$ following uptake in $\mathrm{I}^{-}$solution droplets $(0.5-3 \mathrm{M} \mathrm{NaI})$. The $\mathrm{O}_{3}$ concentrations used were not stated in the paper. They reported a large positive temperature dependence for the $\mathrm{I}^{-}+\mathrm{O}_{3}$ rate coefficient, with an activation energy of $73 \pm 30 \mathrm{~kJ} \mathrm{~mol}^{-1}$. However, the Arrhenius expression they reported $\left(k=1.44 \times 10^{22} \exp (-73080 / R T) \mathrm{M}^{-1} \mathrm{~s}^{-1}\right)$ contains a pre-exponential factor which is roughly 10 orders of magnitude greater than the diffusion limited reaction rate, and therefore appears to be unphysical.

$\mathrm{Hu}$ et al. (1995), using a similar droplet train technique with $\mathrm{I}^{-}$concentrations from $0.5-3 \mathrm{M}$ and $\mathrm{O}_{3}$ in the range $5 \times 10^{12}$ to $1 \times 10^{14} \mathrm{~cm}^{-3}$, measured $k\left(\mathrm{I}^{-}+\mathrm{O}_{3}\right)=4 \times 10^{9} \mathrm{M}^{-1} \mathrm{~s}^{-1}$ at $277 \mathrm{~K}$. Although they do not report a room temperature measurement, the room temperature value for $k\left(\mathrm{I}^{-}+\mathrm{O}_{3}\right)$ appears to be reasonably well established from a number of previous studies (Garland et al., 1980; Hoigné et al., 1985; Magi et al., 1997; Liu et al., 2001), lying in the range (1.2-2.4) $\times 10^{9} \mathrm{M}^{-1} \mathrm{~s}^{-1}$. Thus the $\mathrm{Hu}$ et al. (1995) result implies a slightly negative temperature dependence, although those authors state that within their experimental accuracy the reaction could have been temperature independent.
We therefore assumed the temperature dependence for $k\left(\mathrm{I}^{-}+\mathrm{O}_{3}\right)$ to be zero for modelling the $\mathrm{I}_{2}$ and HOI fluxes using the interfacial kinetic model (Carpenter et al., 2013) and included the various temperature dependences of parameters such as Henry's law constants, diffusion constants, mass transfer velocities, etc. This gave an activation energy for the modelled $\mathrm{I}_{2}$ emission between -6 and $2 \mathrm{~kJ} \mathrm{~mol}^{-1}$ over the concentration ranges of $\mathrm{I}^{-}$and $\mathrm{O}_{3}$ used in the present study, in agreement with the experimental results (Fig. 3). For HOI, the modelled activation energy ranged from 20 to $30 \mathrm{~kJ} \mathrm{~mol}^{-1}$, again within experimental error (Fig. 3).

\subsection{Modelling reactive iodine field measurements}

Recent field observations in the eastern Pacific (Mahajan et al., 2012) and Galápagos Islands (Gómez Martín et al., 2013) have shown a probable link between $\mathrm{IO}_{\mathrm{x}}$ and SST on both temporal and spatial scales (Fig. 4). In contrast, there is either an insignificant or a negative correlation of $\mathrm{IO}_{\mathrm{x}}$ with CDOM and Chl $a$, indicating that an inorganic ocean source is the most likely explanation of the missing contribution to $\mathrm{IO}_{\mathrm{x}}$. It is difficult to compare the available $\mathrm{IO}_{\mathrm{x}}$ measurements as a consequence of the different experimental approaches adopted, which sampled different regions of the marine boundary layer. In addition, there is a lack of concurrent $\mathrm{O}_{3}$ measurements, making the conversion from IO to $\mathrm{IO}_{\mathrm{x}}$ more unreliable. In general, however, integrated over a $1 \mathrm{~km}$ boundary layer, the average daytime $\mathrm{IO}_{\mathrm{x}}$ is around $0.5 \mathrm{pptv}$, with the $\mathrm{IO}_{\mathrm{x}}$ at the surface around 2 pptv. Larger $\mathrm{IO}_{\mathrm{x}}$ mixing ratios are generally observed towards the equator, which gradually decrease at higher latitudes (Fig. 4).

Sea surface iodide (SSI) data, measured (Tsunogai and Henmi, 1971) or derived from measurements of iodate and total iodine (Truesdale et al., 2000), also show a clear latitudinal variation with an increase in iodide towards the equator. According to Truesdale et al. (2000), the polewards increase in $\mathrm{IO}_{3}^{-}$(decrease in $\mathrm{I}^{-}$) corresponds with the overall increase in vertical mixing in the water column, caused by the polewards decrease of SST. Thus, in tropical regions stratification appears to allow $\mathrm{IO}_{3}^{-}$to be reduced to $\mathrm{I}^{-}$in the sea surface either by blocking $\mathrm{IO}_{3}^{-}$replenishment from below, or by facilitating undetermined reduction processes by prolonged isolation of surface water. Note that despite the pre-eminent role attributed to marine biota in the reduction of $\mathrm{IO}_{3}^{-}$to $\mathrm{I}^{-}, \mathrm{IO}_{3}^{-}$ does not correlate well with primary productivity (Truesdale et al., 2000).

From the discussion above, it follows that the surface iodide-ozone emission mechanism and the link between SSI and SST are a likely explanation for the observed correlations between SST and $\mathrm{IO}_{\mathrm{x}}$ measurements. We have therefore combined the measurements of SSI and SST from several cruises in the Atlantic and Pacific oceans (Tsunogai and Henmi, 1971; Elderfield and Truesdale, 1980; McTaggart et al., 1994; Truesdale et al., 2000; Huang et al., 2005) into an Arrhenius-type plot in Fig. 5. This exhibits a sensibly linear 


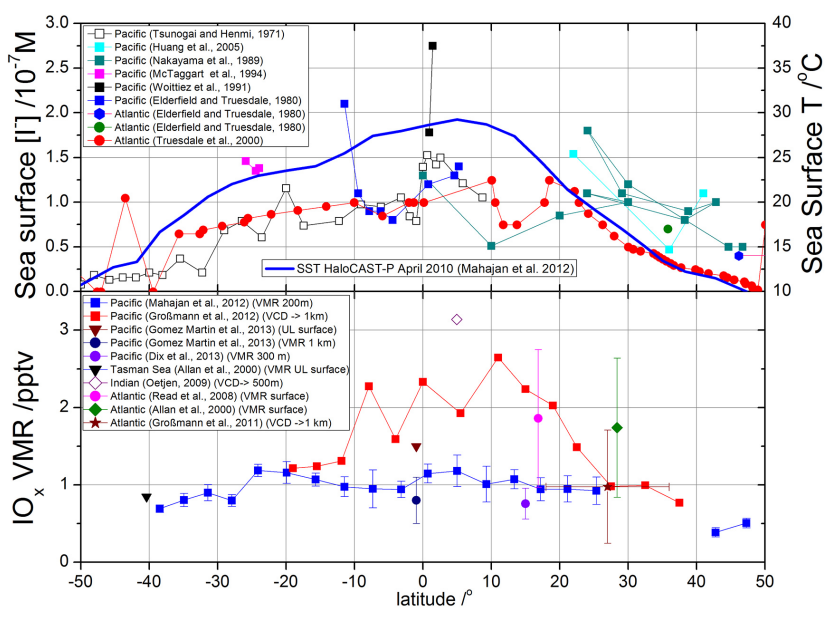

Figure 4. The top panel shows measured sea surface iodide from a number of ship campaigns in the Pacific and Atlantic oceans (Tsunogai and Henmi, 1971; Elderfield and Truesdale, 1980; Nakayama et al., 1989; Woittiez et al., 1991; McTaggart et al., 1994; Truesdale et al., 2000; Huang et al., 2005) along with SST measurements in the Pacific Ocean in March-April 2010 (Mahajan et al., 2012). The bottom panel shows $\mathrm{IO}_{\mathrm{x}}$ volume mixing ratios from campaigns in the open ocean at different latitudes (Allan et al., 2000; Read et al., 2008; Oetjen, 2009; Großmann et al., 2011, 2013; Mahajan et al., 2012; Dix et al., 2013; Gómez Martín et al., 2013). In the legend, VMR refers to volume mixing ratio (layer height stated for MAX-DOAS measurements), VCD refers to vertical column density converted to mixing ratio using the indicated column height, and UL means upper limit. Scaled VCDs are used instead of mixing ratios in some cases where the uncertainty range from radiative transfer calculations obscures the latitudinal variability.

dependence of $\ln \left[\mathrm{I}^{-}\right]$with $\mathrm{SST}^{-1}$ (apart from a small number of outliers marked in red in Fig. 5). The resulting Arrhenius expression

$\left[\mathrm{I}_{(\mathrm{aq})}^{-}\right]=1.46 \times 10^{6} \times \exp \left(\frac{-9134}{\mathrm{SST}}\right)$

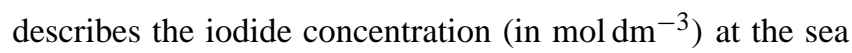
surface as a function of SST (in K). From the $95 \%$ prediction bands plotted in Fig. 5, the uncertainty in $\left[\mathrm{I}^{-}\right]$from Eq. (1) is estimated to be $\sim 50 \%$ of the predicted value. This expression can then be incorporated into the flux expressions derived previously (Carpenter et al., 2013):

$$
\begin{aligned}
F_{\mathrm{HOI}}= & {\left[\mathrm{O}_{3(\mathrm{~g})}\right] \times\left(4.15 \times 10^{5} \times\left(\frac{\left.\sqrt{\left[\mathrm{I}_{(\mathrm{aq})}^{-}\right.}\right]}{\mathrm{ws}}\right)-\left(\frac{20.6}{\mathrm{ws}}\right)\right.} \\
& \left.-23600 \times \sqrt{\left[\mathrm{I}_{(\mathrm{aq})}^{-}\right]}\right) \\
F_{\mathrm{I}_{2}=} & {\left[\mathrm{O}_{3_{(\mathrm{g})}}\right] \times\left[\mathrm{I}_{(\mathrm{aq})}^{-}\right]^{1.3} } \\
\times & \left(1.74 \times 10^{9}-\left(6.54 \times 10^{8} \times \ln \mathrm{ws}\right)\right),
\end{aligned}
$$

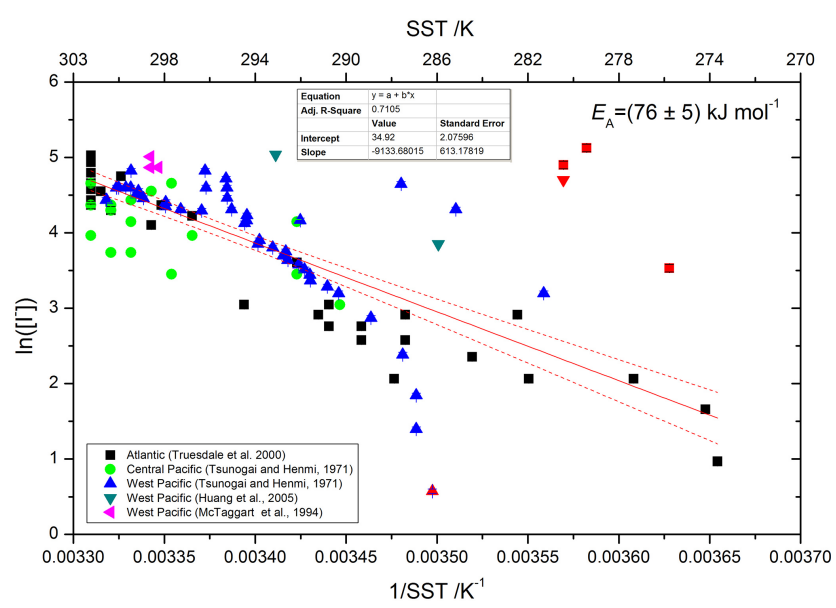

Figure 5. Arrhenius plot of SSI vs. SST field measurements in the Pacific and Atlantic oceans (Tsunogai and Henmi, 1971; McTaggart et al., 1994; Truesdale et al., 2000; Huang et al., 2005). Red points are outliers removed from the fit (most of them correspond to a high iodide episode at low latitude during the Atlantic cruise). The activation energy obtained from the straight line fit is $(76 \pm 5) \mathrm{kJ} \mathrm{mol}^{-1}$ $\left(R^{2}=0.71\right)$. Dashed lines: confidence bands (red) and prediction bands (blue) at $95 \%$.

where the flux is in $n m o l m^{-2} \mathrm{~d}^{-1},\left[\mathrm{O}_{3_{(\mathrm{g})}}\right]$ is in ppbv (or $\left.\mathrm{nmol} \mathrm{mol}^{-1}\right),\left[\mathrm{I}_{(\mathrm{aq})}^{-}\right]$in $\mathrm{mol} \mathrm{dm}^{-3}$ and wind speed (ws) in $\mathrm{m} \mathrm{s}^{-1}$.

Equations (2) and (3) are room temperature expressions, since Carpenter et al. (2013) did not consider the potential temperature dependence of any processes in the interfacial layer. As discussed above, a large temperature dependence of the $\mathrm{I}^{-}+\mathrm{O}_{3}$ reaction can be ruled out, but the modest experimental precision does not tightly constrain the activation energies of the iodine fluxes (see Fig. 3). The interfacial layer model predicts activations energies for $I_{2}$ and HOI emission of $\sim-2 \mathrm{~kJ} \mathrm{~mol}^{-1}$ and $25 \mathrm{~kJ} \mathrm{~mol}^{-1}$, respectively, which are within the experimental uncertainty of our measurements. Table 1 presents a summary of the relative error $\left(F_{X}(T)-F_{X}(293 \mathrm{~K})\right) / F_{X}(293 \mathrm{~K})$ made when using the $293 \mathrm{~K}$ expressions (2) and (3) at 283 and $303 \mathrm{~K}$ using different values for the activation energies. For this exercise, an additional Arrhenius-type exponential factor is assumed in (2) and (3), and the experimental uncertainty limits for the activation energies ( $E_{\text {up }}$ and $\left.E_{\text {low }}\right)$ and the activation energies derived from the interface kinetic model $\left(E_{\text {model }}\right)$ are considered. The uncertainties in the HOI flux arising from the uncertainty in the activation energy are larger than for the $\mathrm{I}_{2}$ flux, and since HOI this is the major inorganic species emitted, this must be kept in mind when modelling field data at SST other than $293 \mathrm{~K}$.

Equations (1)-(3) provide a convenient parameterisation of the inorganic iodine flux for modelling purposes, since SST measurements are much more widely available than SSI measurements. Note that the fluxes are predicted to be 
Table 1. Relative differences of the inorganic iodine fluxes at $283 \mathrm{~K}$ and $303 \mathrm{~K}$ with respect to the $293 \mathrm{~K}$ values, for the experimental confidence limits and the modelled values of the activation energies.

\begin{tabular}{rrrr|rrr}
\hline & \multicolumn{3}{c}{$\mathrm{I}_{2}$} & \multicolumn{3}{c}{ HOI } \\
\cline { 2 - 7 } & $E_{\text {low }}$ & $E_{\text {up }}$ & $E_{\text {model }}$ & $E_{\text {low }}$ & $E_{\text {up }}$ & $E_{\text {model }}$ \\
\cline { 2 - 7 } & $-25 \mathrm{~kJ} \mathrm{~mol}^{-1}$ & $11 \mathrm{~kJ} \mathrm{~mol}^{-1}$ & $-2 \mathrm{~kJ} \mathrm{~mol}^{-1}$ & $-33 \mathrm{~kJ} \mathrm{~mol}^{-1}$ & $67 \mathrm{~kJ} \mathrm{~mol}^{-1}$ & $25 \mathrm{~kJ} \mathrm{~mol}^{-1}$ \\
\hline $303 \mathrm{~K}$ & $29 \%$ & $-16 \%$ & $3 \%$ & $37 \%$ & $-153 \%$ & $-41 \%$ \\
$283 \mathrm{~K}$ & $-45 \%$ & $15 \%$ & $-3 \%$ & $-63 \%$ & $63 \%$ & $31 \%$ \\
\hline
\end{tabular}

highest under conditions of high $\left[\mathrm{O}_{3(\mathrm{~g})}\right]$, high $\left[\mathrm{I}_{(\mathrm{aq})}^{-}\right]$, and/or low wind speed. The wind speed relationship arises from the assumption that wind shear (only) drives turbulent mixing of the interfacial layer with bulk seawater, thus reducing the proportion of $\mathrm{I}_{2}$ and HOI evading into the atmosphere (Carpenter et al., 2013).

To test these expressions, daytime average measurements of $\mathrm{IO}_{\mathrm{x}}$ recorded during the HaloCAST-P cruise in the eastern Pacific were compared with model output from the 1-D model THAMO (Saiz-Lopez et al., 2008). The HaloCAST$\mathrm{P}$ cruise (Mahajan et al., 2012) was a 4-week cruise from 27 March to 26 April 2010, starting at Punta Arenas at the southern tip of Chile and continuing northwards to Seattle, USA. Measurements of IO were performed using a MultiAxis Differential Optical Absorption Spectroscopy (MAXDOAS) instrument, as well as measurements of $\mathrm{CH}_{3} \mathrm{I}$ in seawater and air using gas chromatography-mass spectrometry (GC-MS) along with ancillary data such as SST, ws, Chl $a$, $\mathrm{CDOM}$ and SSS. $\mathrm{IO}_{\mathrm{x}}$ mixing ratios were derived from the observed $\mathrm{IO}$ and CAM-Chem modelled $\mathrm{O}_{3}$, assuming low $\mathrm{NO}_{\mathrm{x}}$ concentrations $\left(\mathrm{O}_{3}\right.$ was not measured during the cruise), for which the $\mathrm{IO}_{\mathrm{x}}$ partitioning is controlled by IO photolysis and the $\mathrm{I}+\mathrm{O}_{3}$ reaction, resulting in an $\mathrm{IO} / \mathrm{I}$ ratio of $\sim 0.12 *\left[\mathrm{O}_{3}\right] \mathrm{ppbv}^{-1}$ (for $\mathrm{SZA}<60^{\circ}$ ).

Using the observed SST and ws from the HaloCAST-P cruise, and modelled $\mathrm{O}_{3}$ from CAM-Chem (Fig. 6) (Mahajan et al., 2012), the predicted HOI and $\mathrm{I}_{2}$ fluxes were calculated using Eqs. (1)-(3). The sum of these is plotted against latitude in Fig. 6a and against the measured $\mathrm{IO}$ and derived $\mathrm{IO}_{\mathrm{x}}$ in Fig. 7. The three points highlighted in red in Fig. 7 were excluded from the linear regression fits. These excluded points correspond to measurements at the equatorial front in the Pacific Ocean (15-25 N, see Fig. 6d), where the modelled $\mathrm{O}_{3}$ concentrations are considerably more uncertain than earlier in the campaign. In this region the $\mathrm{O}_{3}$ concentration is highly dependent on the water vapour concentration, which in turn will depend on the season and year due to fluctuations in temperature. As a result, the climatological $\mathrm{O}_{3}$ output from CAM-Chem may not be representative of the actual $\mathrm{O}_{3}$ during the Thompson cruise. The $R^{2}$ correlation coefficients with the $\mathrm{IO}_{\mathrm{x}}$ and IO measurements (after excluding these points) were only 0.10 and $0.15(p=0.09)$, respectively. An interesting point to note is the significant intercept observed in both plots; $0.66 \mathrm{pptv}$ for $\mathrm{IO}_{\mathrm{x}}$ and $0.48 \mathrm{pptv}$ for IO. This may be indicative of the contribution of iodocarbons to the total $\mathrm{IO}_{\mathrm{x}}$. The modelling work performed by Mahajan et al. (2012) suggested that around $30 \%$ of the $\mathrm{IO}_{\mathrm{x}}$ could be explained by the observed emissions of $\mathrm{CH}_{3} \mathrm{I}$, and there are likely other iodocarbon species which will also contribute. As such, the 1-D model THAMO was initiated using only halocarbon fluxes with no contribution from the additional inorganic iodine emissions so that the resulting IO and $\mathrm{IO}_{\mathrm{x}}$ matched the observed intercepts. These values were then fixed for subsequent model runs.

THAMO is a 1-D chemistry transport model (SaizLopez et al., 2008) consisting of 200 stacked boxes of $5 \mathrm{~m}$ resolution giving a total height of $1 \mathrm{~km} . K_{z z}$ profiles were constructed for each measurement point based on the measured ws, assuming convective conditions and a capped boundary layer of $1 \mathrm{~km}$. A number of species were constrained in the model using typical measured values over the open ocean: $\left[\mathrm{NO}_{\mathrm{x}}\right]=25 \mathrm{pptv},[\mathrm{CO}]=110 \mathrm{ppbv}$, $[\mathrm{DMS}]=30 \mathrm{pptv},\left[\mathrm{CH}_{4}\right]=1820 \mathrm{ppbv},[$ ethane $]=925 \mathrm{pptv}$, $\left[\mathrm{CH}_{3} \mathrm{CHO}\right]=970 \mathrm{pptv}, \quad[\mathrm{HCHO}]=500 \mathrm{pptv}, \quad$ [isoprene $]=10 \mathrm{pptv}, \quad[$ propane $]=60 \mathrm{pptv}, \quad[$ propene $]=20 \mathrm{pptv}$ (Carpenter et al. (2013), Supplement). Equations (1)-(3) were included in THAMO to calculate the HOI and $\mathrm{I}_{2}$ fluxes, driven by the measured ws and SST, and the CAM-Chem modelled $\mathrm{O}_{3}$ mixing ratios at each point on the Thompson cruise track. Because $\mathrm{HOI}$ and $\mathrm{I}_{2}$ can build up in the MBL close to the ocean surface, and therefore suppress the emission from the sea-air interface, the Henry's law constants and transfer coefficients $\left(K_{\mathrm{T}}\right)$ for $\mathrm{HOI}$ and $\mathrm{I}_{2}$ were calculated directly in the model (as described in Carpenter et al. (2013), Supplement).

The IO and $\mathrm{IO}_{\mathrm{x}}$ predicted by THAMO, along with the measured $\mathrm{IO}$ and derived $\mathrm{IO}_{\mathrm{x}}$, were then plotted against latitude (Fig. 6d) and against the total inorganic iodine flux (Fig. 8). Note that the model $\mathrm{IO}$ and $\mathrm{IO}_{\mathrm{x}}$ was computed by averaging over the first $200 \mathrm{~m}$ of the model vertical profiles (first 40 boxes) using only daylight data. This was done because the measured $\mathrm{IO}$ and $\mathrm{IO}_{\mathrm{x}}$ mixing ratios were calculated from the MAX-DOAS IO slant column densities (dSCDs) measured with a $1^{\circ}$ elevation angle, which should only be sensitive to the first $200 \mathrm{~m}$ in the boundary layer. The IO mixing ratios were then calculated using the $\mathrm{O}_{4}$ method 


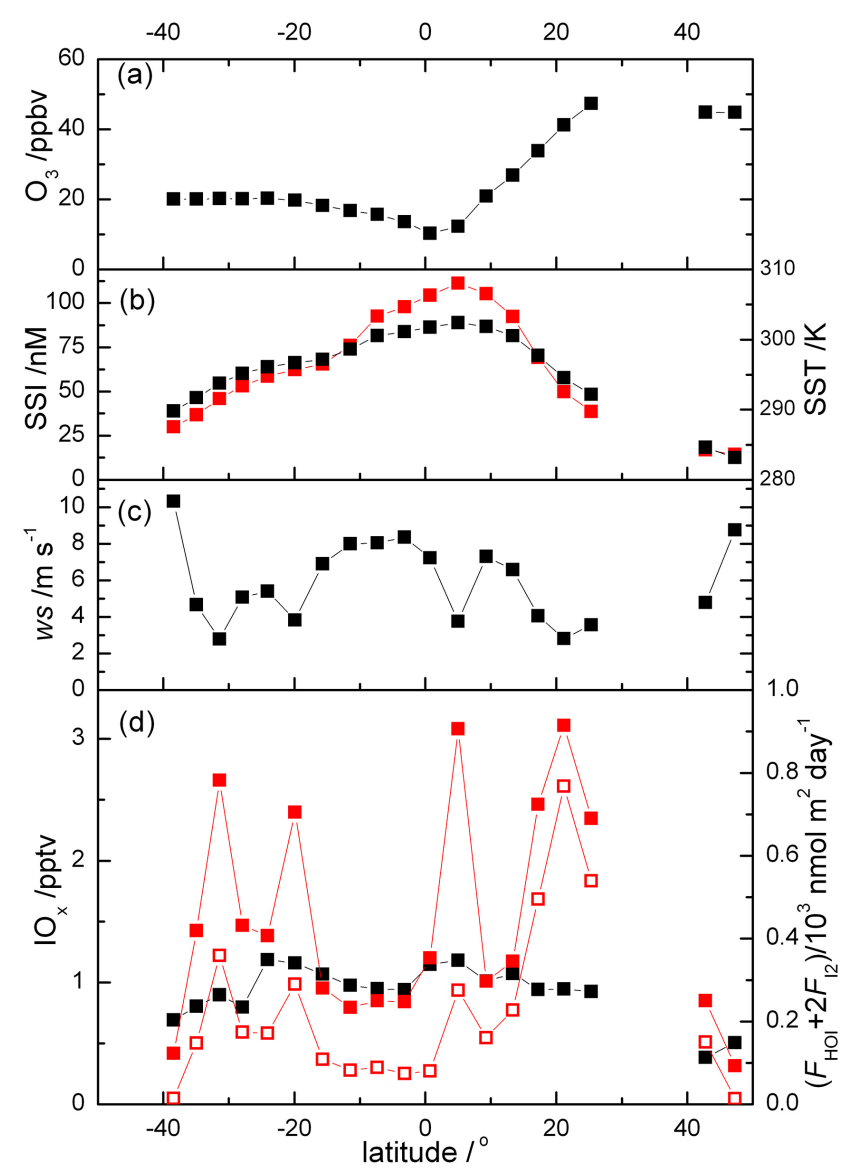

Figure 6. HaloCAST-P cruise data (Mahajan et al., 2012): (a) ozone (modelled using CAM-Chem, see text); (b) sea surface temperature (black, right axis) and iodide (red, left axis) derived from SST using Eq. (1); (c) wind speed; and (d) $\mathrm{IO}_{\mathrm{x}}$ (left axis) and inorganic iodine flux (right axis). (d) shows $\mathrm{IO}_{\mathrm{x}}$ derived from measurements (black) and modelled in this work using THAMO employing the shown inorganic iodine source function (empty red squares).

(Mahajan et al., 2012), and for quality control only daylight data with $\mathrm{SZA}<60^{\circ}$ were used.

Although there is reasonable agreement for the points with lower computed inorganic iodine flux, the predicted IO and $\mathrm{IO}_{\mathrm{x}}$ is about a factor of 2 larger than measured at relatively high $\mathrm{HOI}$ and $\mathrm{I}_{2}$ fluxes. Figure $6 \mathrm{~d}$ also shows how the modelled $\mathrm{IO}_{\mathrm{x}}$ around $20^{\circ} \mathrm{N}$ does not scale with the enhanced calculated flux at this latitude (equatorial front). The model sensitivity to the three key parameters in Eqs. (1)-(3) is described below, leading to a discussion of the possible reasons for the discrepancies observed.

\subsection{Model sensitivity to ozone, SST (iodide) and wind speed}

Sensitivity studies were conducted to investigate the effect of changing $\mathrm{O}_{3}$, SST and wind speed on the inorganic iodine fluxes predicted by Eqs. (1)-(3). The results of these inves-

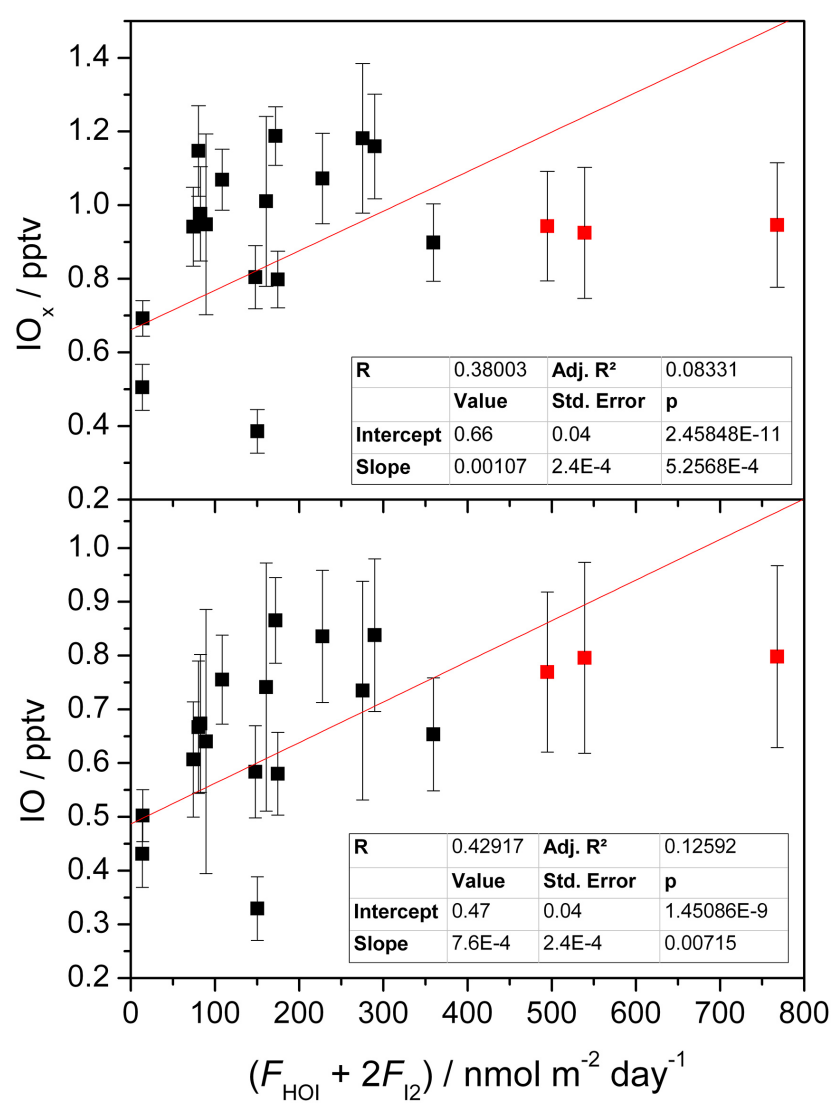

Figure 7. Measured $\mathrm{IO}_{\mathrm{x}}$ (top panel) and IO (bottom panel) from the HaloCAST-P cruise against predicted inorganic iodine flux from the parameterised flux expressions for each data point. Points in red were excluded from the linear fit.

tigations are shown in Fig. 9. There is a weak sensitivity of IO to increasing $\mathrm{O}_{3}\left(\sim 0.01 \mathrm{pptv} \mathrm{ppbv}^{-1}\right.$ at noon), while $\mathrm{IO}_{\mathrm{x}}$ decreases from 5 to 25 ppbv ozone and then converges with IO. This is because at higher $\mathrm{O}_{3}$ concentrations most of $\mathrm{IO}_{\mathrm{x}}$ is in the IO form, and a larger fraction of IO undergoes selfreaction and ends up as $\mathrm{I}_{\mathrm{x}} \mathrm{O}_{\mathrm{y}}$ (there is around 10 times more $\mathrm{I}_{\mathrm{x}} \mathrm{O}_{y}$ produced at $50 \mathrm{ppbv}$ compared to $5 \mathrm{ppbv}$ ) which acts as a sink for $\mathrm{IO}_{\mathrm{x}}$ in the model, forming IOPs. At low $\mathrm{O}_{3}$ concentration ( 5 ppbv) a significant part of the reactive iodine remains as less reactive I atoms rather than being converted to $\mathrm{IO}$, and therefore the $\mathrm{IO}_{\mathrm{x}}$ remains high. In summary, the IO second-order losses counterbalance the significant increase in inorganic iodine flux for a 10-fold increase in ozone and may explain why the large increase of calculated inorganic flux around the equatorial front (Fig. 6d) does not reflect in the modelled $\mathrm{IO}_{\mathrm{x}}$ mixing ratio.

An interesting result of this exercise is that it shows that IO is also produced at night (see Fig. 9). This is due to the presence of $\mathrm{NO}_{3}$ and its reaction with the freshly emitted $\mathrm{I}_{2}$ (Saiz-Lopez and Plane, 2004) This reaction produces I atoms which can further react with $\mathrm{O}_{3}$ to produce IO. This reaction would not be important under clean conditions due to the 


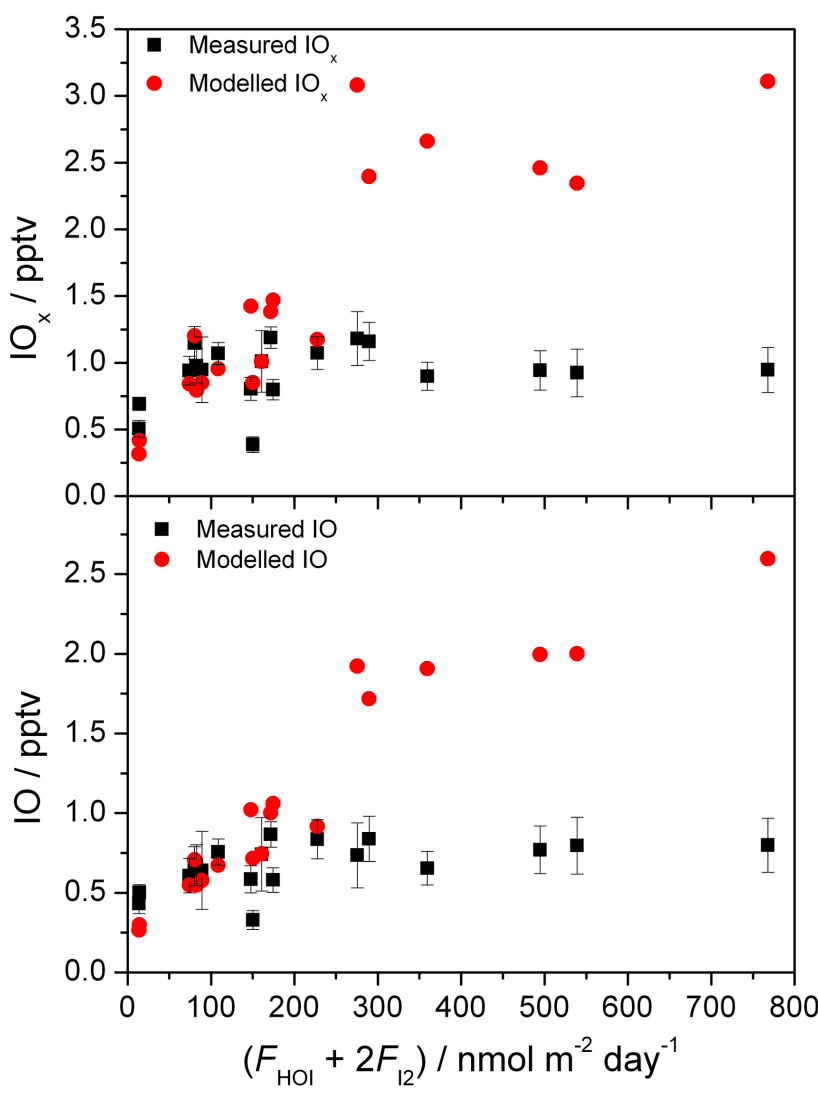

Figure 8. Measured (black squares) and THAMO modelled (red circles) $\mathrm{IO}_{\mathrm{x}}$ (top panel) and IO (bottom panel) for all HaloCAST-P cruise data against predicted inorganic iodine flux from the parameterised expressions.

very low $\mathrm{NO}_{\mathrm{x}}$ levels and indeed, the modelled IO is well below the detection limit of typical DOAS instruments. This may, however, be an important reaction for polluted conditions with much higher $\mathrm{NO}_{\mathrm{x}}$ levels and there is the possibility that $\mathrm{HOI}$ will also react with $\mathrm{NO}_{3}$ to produce IO.

The increase in $\mathrm{IO}$ and $\mathrm{IO}_{\mathrm{x}}$ with SST is explained by the increase in SST leading to a higher predicted iodide concentration in the surface layer (Eq. 1). This will in turn lead to an increased predicted inorganic iodine flux from the flux expressions above. At a fixed ozone concentration of $25 \mathrm{pptv}$, the modelled $\mathrm{IO}_{\mathrm{x}}$ shows a sensitivity to SST of $\sim 0.05 \mathrm{pptv} \mathrm{K}^{-1}$, which compares well with the 0.03 pptv $\mathrm{K}^{-1}$ observed in the HaloCAST-P campaign.

Wind speed has a dramatic effect on the predicted IO and $\mathrm{IO}_{\mathrm{x}}$, with an increase observed at lower wind speeds. It is clear from inspection of Eq. (2) that the HOI flux will be heavily dependent on the wind speed due to the $\mathrm{ws}^{-1}$ relationship. This means that Eq. (2) will become invalid at low wind speeds $\left(<3 \mathrm{~m} \mathrm{~s}^{-1}\right)$. A comparison of the predicted HOI and $I_{2}$ fluxes using Eqs. (1)-(3) with the output of the kinetic interfacial model (Carpenter et al., 2013) shows that there is increasing deviation at wind speeds less than $3 \mathrm{~m} \mathrm{~s}^{-1}$. For
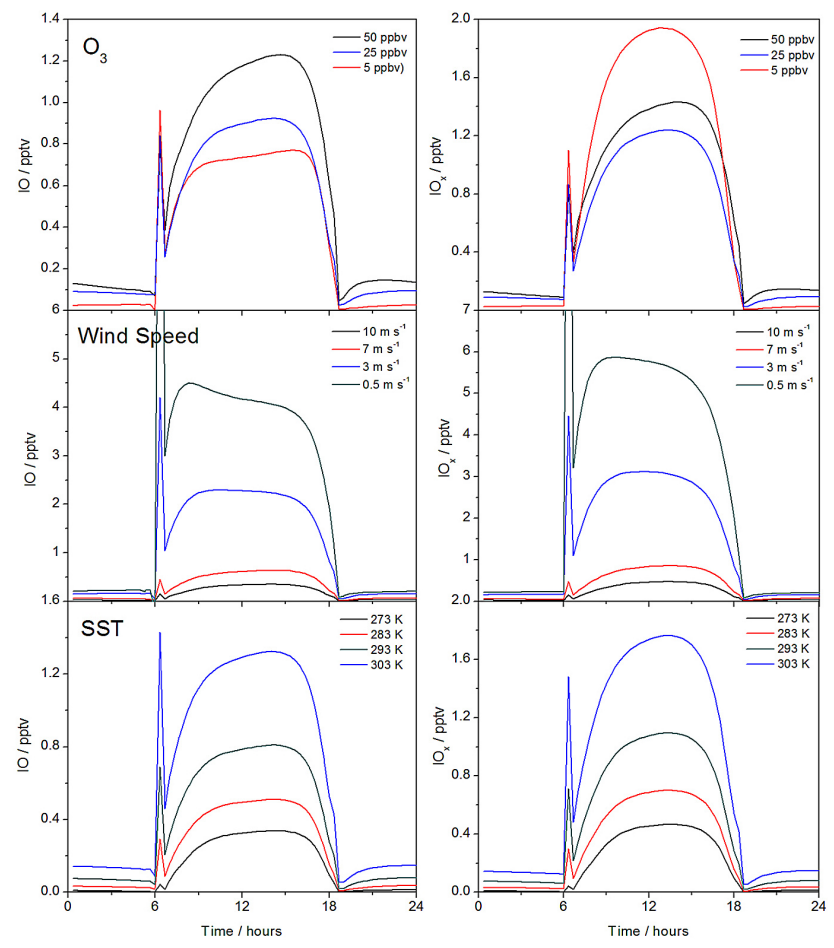

Figure 9. Effect of changing flux parameters on the THAMO modelled mixing ratios of $\mathrm{IO}$ and $\mathrm{IO}_{\mathrm{x}}$ averaged over the first $200 \mathrm{~m}$. For each sensitivity test, the two fixed parameters are set to the average of the HaloCAST-P campaign: $\left[\mathrm{O}_{3}\right]=25 \mathrm{ppbv}$, $\mathrm{ws}=6 \mathrm{~m} \mathrm{~s}^{-1}$ and SST $=296 \mathrm{~K}$. Top panels: modelled diurnal IO and $\mathrm{IO}_{\mathrm{x}}$ with varying $\mathrm{O}_{3}$ (black line $=50 \mathrm{ppbv}$, blue line $=25 \mathrm{ppbv}$, red line $=5$ ppbv). Middle panels: modelled diurnal $\mathrm{IO}$ and $\mathrm{IO}_{\mathrm{x}}$ with varying wind speed (black line $=10 \mathrm{~m} \mathrm{~s}^{-1}$, red line $=7 \mathrm{~m} \mathrm{~s}^{-1}$, blue line $=3 \mathrm{~m} \mathrm{~s}^{-1}$, turquoise line $=0.5 \mathrm{~m} \mathrm{~s}^{-1}$ ). Bottom panels: modelled diurnal $\mathrm{IO}$ and $\mathrm{IO}_{\mathrm{x}}$ with varying SST (black line $=273 \mathrm{~K}$, red line $=283 \mathrm{~K}$, turquoise line $=293 \mathrm{~K}$, blue line $=303 \mathrm{~K}$ ).

instance, Eqs. (1)-(3) overpredict the combined HOI and $\mathrm{I}_{2}$ fluxes by a factor of two at a wind speed of $0.5 \mathrm{~m} \mathrm{~s}^{-1}$.

\subsection{Discussion of discrepancies between observed and predicted IO}

The high predicted inorganic iodine flux around $20^{\circ} \mathrm{N}$ is generated by high $\mathrm{O}_{3}$ (from CAM-Chem) and low measured wind speeds (see Fig. 6a, c and d). As mentioned above, the high $\mathrm{O}_{3}$ from CAM-Chem may not accurately represent the $\mathrm{O}_{3}$ during the Thompson cruise. In order to investigate this possibility, the model was run for the conditions of the three highest flux points in Fig. 8, varying the $\mathrm{O}_{3}$ concentration until the resulting IO matched the measured mixing ratios (the $\mathrm{IO}$ was used to match the observations, as the $\mathrm{IO}_{\mathrm{x}}$ measurements were derived from the $\mathrm{O}_{3}$ mixing ratios predicted by CAM-Chem). The $\mathrm{O}_{3}$ had to be reduced to 2 ppbv before the observations could be matched. In fact, open ocean ozone mixing ratios below the detection limit of commercial instruments $(\sim 2$ ppbv) have been reported (Gómez Martín 
et al., 2013; Großmann et al., 2013). However, we have also shown above that an enhanced iodine inorganic flux due to high ozone mixing ratios does not result in a large increase of $\mathrm{IO}_{\mathrm{x}}$ mixing ratios due the loss to IOPs via IO self-reaction. This is clearly illustrated in Fig. 6 by similar modelled $\mathrm{IO}_{\mathrm{x}}$ at $5^{\circ} \mathrm{N}$ and $20^{\circ} \mathrm{N}$ for similar wind speed and a difference of a factor of $\sim 4$ in the climatological ozone mixing ratios.

The model overpredictions could also be attributed to deviations of the iodide concentration from the parameterisation based on SST measurements. As shown in Fig. 5, the general trend of SSI is to follow the changes in SST. However, there are a number of localised phenomena which can alter this relationship, such as upwelling, lateral advection and rainfall (Nakayama et al., 1989; Truesdale et al., 2000). If the iodide at some points of the cruise track was significantly lower than indicated by the SST measurements this would lead to a reduced inorganic iodine flux, and therefore lower IO and $\mathrm{IO}_{\mathrm{x}}$. It is conceivable that SSI could show seasonal variability around the equatorial front which is not captured by the SST parameterisation. Note, however, that a related parameter such as SSS (Mahajan et al., 2012) shows a smooth behaviour throughout the HaloCAST$\mathrm{P}$ cruise, which does not suggest strong localised phenomena affecting SSI. Regarding a potential depletion of iodide in the top layer of the ocean, at the highest calculated inorganic iodine flux $\left(\sim 800 \mathrm{nmol} \mathrm{m}^{-2} \mathrm{~d}^{-1}\right)$, over the course of $24 \mathrm{~h}$ the iodide would be depleted in a layer at the surface of around $8 \mathrm{~mm}$. Using the diffusion coefficient for iodide of $2 \times 10^{-5} \mathrm{~cm}^{2} \mathrm{~s}^{-1}$ (Friedman and Kennedy, 1955), it would take around $2.5 \mathrm{~h}$ for the iodide in this layer to be replenished from below. Hence this explanation does not appear likely.

The sensitivity analysis in the previous section shows that the model is extremely sensitive to ws. In fact, a comparison of Fig. 6c and d shows that a correlation exists between deviation of simulated mixing ratios from observed data and wind speeds equal to or lower than $3 \mathrm{~m} \mathrm{~s}^{-1}$. Below, we examine several reasons which could lead to an overestimation of $\mathrm{IO}_{\mathrm{x}}$ by the model as a result of insufficient detail in the treatment of wind-related phenomena.

First, it is plausible that the interfacial model overpredicts $\mathrm{I}_{2}$ and HOI emissions at very low wind speeds. The interfacial model only includes wind shear-driven turbulent mixing of the interfacial layer with bulk seawater. However, vertical transport from the surface to the bulk mixed layer is governed by a combination of processes, including convection generated by cooling at the surface, Langmuir turbulence, rainfall, etc. Convection is important for mixing when wind is in the low to intermediate speed regime (Rutgersson et al., 2011), thus it is likely that mixing of interfacial iodine to bulk waters is underestimated under low wind speed conditions. Second, it can be hypothesised that reduced wind speeds over the ocean enable the formation of organic films at the surface (Frew et al., 2004), inhibiting the sea-to-air exchange of $I_{2}$ and HOI (Reeser and Donaldson, 2011; Shaw and Carpenter, 2013).
A further possibility is that low wind speeds result in much less vertical mixing above the surface of the ocean, causing an accumulation of $\mathrm{I}_{2}$ and HOI immediately above the ocean surface, which would suppress further emission due to equilibration. High mixing ratios of $\mathrm{I}_{2}$ and $\mathrm{HOI}$ above the surface during daylight hours could lead to sufficient IO concentrations for IOP formation to occur (this is a highly non-linear process, as shown by Mahajan et al. 2010), reducing the overall IO mixing ratio over the first $200 \mathrm{~m}$. To test this possibility, the $K_{z z}$ profile for the three highest predicted IO concentrations was adjusted to be an order of magnitude lower than originally calculated in the lowest $5 \mathrm{~m}$ box. However, this was found to have a limited effect on the modelled daytime average IO, with a reduction of only around $1 \%$. Note also that reduced atmospheric vertical mixing at low ws would retain the IO close to the ocean surface for a number of hours, creating a much steeper vertical gradient. The MAX-DOAS daytime average could possibly be insensitive to the IO that is very close to the ocean surface (the scattering altitude in the visible even for an elevation angle of $1^{\circ}$ is tens of metres). If low ws conditions are sustained during the day the boundary layer would not develop as efficiently and so for the same scattering altitude, but lower mixing rates, a daytime averaged MAX-DOAS measurement could be lower under low ws, compared to high ws, for a very reactive species.

\section{Conclusions}

The experimental results reported show that over the large range of conditions considered in the laboratory, parameters such as salinity can have a large effect on the resulting total inorganic iodine flux, although these effects are likely to be minimal under real seawater conditions where the variations in salinity tend to be relatively small. None of the organics used in the reported experiments had any significant effect on the resulting inorganic iodine fluxes, but we cannot rule out the possibility that surface organic films may play a role in limiting the transfer of $\mathrm{HOI}$ and $\mathrm{I}_{2}$ to the gas phase in real seawater.

SST was found to be a good proxy for SSI concentrations reported in the literature, and due to the wide availability of SST measurements, the derived relationship provides a useful tool for atmospheric modelling purposes. Modelled and measured $\mathrm{IO}$ and $\mathrm{IO}_{\mathrm{x}}$ were found to be in reasonable agreement when the predicted $\mathrm{I}_{2}$ and HOI fluxes were low, although under low wind speed conditions there is a substantial over-prediction in the model. A limiting factor may need to be introduced for modelling $\mathrm{IO}$ and $\mathrm{IO}_{\mathrm{x}}$ under very calm ocean conditions. Based on the comparison with measurements in this paper, a simple approach would be to set a lower limit of ws to $3 \mathrm{~m} \mathrm{~s}^{-1}$ when implementing Eqs. (1)-(3) in a model. The modelling results indicate that consideration of the inorganic iodine flux from reaction of $\mathrm{O}_{3}$ and $\mathrm{I}^{-}$is necessary for reproducing measurements of iodine oxides over the open ocean, although further 
experimental work is required to refine the parameterised flux expressions. These should be also tested against other long term/wide spatial coverage observations of reactive iodine recently reported.

Edited by: M. Ammann

\section{References}

Allan, B. J., McFiggans, G., Plane, J. M. C., and Coe, H.: Observations of iodine monoxide in the remote marine boundary layer, J. Geophys. Res.-Atmos., 105, 14363-14369, doi:10.1029/1999jd901188, 2000.

Atkinson, H. M., Huang, R.-J., Chance, R., Roscoe, H. K., Hughes, C., Davison, B., Schönhardt, A., Mahajan, A. S., Saiz-Lopez, A., Hoffmann, T., and Liss, P. S.: Iodine emissions from the sea ice of the Weddell Sea, Atmos. Chem. Phys., 12, 11229-11244, doi:10.5194/acp-12-11229-2012, 2012.

Baxter, G. P., Hickey, C. H., and Holmes, W. C.: THE VAPOR PRESSURE OF IODINE, J. Am. Chem. Soc., 29, 127-136, doi:10.1021/ja01956a004, 1907.

Caleman, C., Hub, J. S., van Maaren, P. J., and van der Spoel, D.: Atomistic simulation of ion solvation in water explains surface preference of halides, P. Natl. Acad. Sci. USA, 108, 6838-6842, doi:10.1073/pnas.1017903108, 2011.

Carpenter, L. J., MacDonald, S. M., Shaw, M. D., Kumar, R., Saunders, R. W., Parthipan, R., Wilson, J., and Plane, J. M. C.: Atmospheric iodine levels influenced by sea surface emissions of inorganic iodine, Nat. Geosci., 6, 108-111, doi:10.1038/ngeo1687, 2013.

Ćosović, B., Żutić, V., Vojvodić, V., and Pleše, T.: Determination of surfactant activity and anionic detergents in seawater and sea surface microlayer in the Mediterranean, Mar. Chem., 17, 127139, doi:10.1016/0304-4203(85)90069-6, 1985.

Dix, B., Baidar, S., Bresch, J. F., Hall, S. R., Schmidt, K. S., Wang, S., and Volkamer, R.: Detection of iodine monoxide in the tropical free troposphere, P. Natl. Acad. Sci. USA, 110, 2035-2040, doi:10.1073/pnas.1212386110, 2013.

Elderfield, H. and Truesdale, V. W.: On the biophilic nature of iodine in seawater, Earth Planet. Sc. Lett., 50, 105-114, 1980.

Frew, N. M., Bock, E. J., Schimpf, U., Hara, T., Haußecker, H., Edson, J. B., McGillis, W. R., Nelson, R. K., McKenna, S. P., Uz, B. M., and Jähne, B.: Air-sea gas transfer: Its dependence on wind stress, small-scale roughness, and surface films, J. Geophys. Res.-Oceans, 109, C08S17, doi:10.1029/2003jc002131, 2004.

Friedman, A. M. and Kennedy, J. W.: The self-diffusion coefficients of potassium, cesium, iodide and chloride ions in aqueous solutions, J. Am. Chem. Soc., 77, 4499-4501, doi:10.1021/ja01622a016, 1955.

Garland, J. A. and Curtis, H.: Emission of iodine from the seasurface in the presence of ozone, J. Geophys. Res.-Oc. Atm., 86, 3183-3186, 1981.

Garland, J. A., Elzerman, A. W., and Penkett, S. A.: The mechanism for dry deposition of ozone to seawater surfaces, J. Geophys. Res.-Oc. Atm., 85, 7488-7492, doi:10.1029/JC085iC12p07488, 1980.

Ghosal, S., Hemminger, J. C., Bluhm, H., Mun, B. S., Hebenstreit, E. L. D., Ketteler, G., Ogletree, D. F., Requejo, F. G., and Salmeron, M.: Electron spectroscopy of aqueous solution inter- faces reveals surface enhancement of halides, Science, 307, 563 566, doi:10.1126/science.1106525, 2005.

Gladich, I., Shepson, P. B., Carignano, M. A., and Szleifer, I.: Halide Affinity for the Water-Air Interface in Aqueous Solutions of Mixtures of Sodium Salts, J. Phys. Chem. A, 115, 5895-5899, doi:10.1021/jp110208a, 2011.

Gómez Martín, J. C., Mahajan, A. S., Hay, T. D., Prados-Román, C., Ordóñez, C., MacDonald, S. M., Plane, J. M. C., Sorribas, M., Gil, M., Paredes Mora, J. F., Agama Reyes, M. V., Oram, D. E., Leedham, E., and Saiz-Lopez, A.: Iodine chemistry in the eastern Pacific marine boundary layer, J. Geophys. Res.-Atmos., 118, 887-904, doi:10.1002/jgrd.50132, 2013.

Großmann, K., Tschritter, J., Holla, R., Pöhler, D., Frieß, U., and Platt, U.: MAX-DOAS measurements of $\mathrm{BrO}$ and $\mathrm{IO}$ over the Eastern Tropical North Atlantic, Geophys. Res. Abstr., 13, EGU2011-8054-2011, 2011.

Großmann, K., Frieß, U., Peters, E., Wittrock, F., Lampel, J., Yilmaz, S., Tschritter, J., Sommariva, R., von Glasow, R., Quack, B., Krüger, K., Pfeilsticker, K., and Platt, U.: Iodine monoxide in the Western Pacific marine boundary layer, Atmos. Chem. Phys., 13, 3363-3378, doi:10.5194/acp-13-3363-2013, 2013.

Hayase, S., Yabushita, A., Kawasaki, M., Enami, S., Hoffmann, M. R., and Colussi, A. J.: Heterogeneous Reaction of Gaseous Ozone with Aqueous Iodide in the Presence of Aqueous Organic Species, J. Phys. Chem. A, 114, 6016-6021, doi:10.1021/jp101985f, 2010.

Hayase, S., Yabushita, A., and Kawasaki, M.: Iodine Emission in the Presence of Humic Substances at the Water's Surface, J. Phys. Chem. A, 116, 5779-5783, doi:10.1021/jp2048234, 2012.

Hoigné, J., Bader, H., Haag, W. R., and Staehelin, J.: Rate constants of reactions of ozone with organic and inorganic compounds in water - III. Inorganic compounds and radicals, Water Res., 19, 993-1004, doi:10.1016/0043-1354(85)90368-9, 1985.

Hore, D. K., Beaman, D. K., and Richmond, G. L.: Surfactant headgroup orientation at the air/water interface, J. Am. Chem. Soc., 127, 9356-9357, doi:10.1021/ja051492o, 2005.

Hu, J. H., Shi, Q., Davidovits, P., Worsnop, D. R., Zahniser, M. S., and Kolb, C. E.: Reactive Uptake of $\mathrm{Cl} 2(\mathrm{~g})$ and $\mathrm{Br} 2(\mathrm{~g})$ by Aqueous Surfaces as a Function of Br- and I- Ion Concentration: The Effect of Chemical Reaction at the Interface, J. Phys. Chem., 99, 8768-8776, doi:10.1021/j100021a050, 1995.

Huang, Z., Ito, K., Morita, I., Yokota, K., Fukushi, K., Timerbaev, A. R., Watanabe, S., and Hirokawa, T.: Sensitive monitoring of iodine species in sea water using capillary electrophoresis: vertical profiles of dissolved iodine in the Pacific Ocean, J. Environ. Monitor., 7, 804-808, doi:10.1039/b501398d, 2005.

Jones, C. E., Hornsby, K. E., Sommariva, R., Dunk, R. M., Von Glasow, R., McFiggans, G., and Carpenter, L. J.: Quantifying the contribution of marine organic gases to atmospheric iodine, Geophys. Res. Lett., 37, L18804, doi:10.1029/2010g1043990, 2010.

Jungwirth, P. and Tobias, D. J.: Specific Ion Effects at the Air/Water Interface, Chem. Rev., 106, 1259-1281, doi:10.1021/cr0403741, 2005.

Lawler, M. J., Mahajan, A. S., Saiz-Lopez, A., and Saltzman, E. S.: Observations of $\mathrm{I}_{2}$ at a remote marine site, Atmos. Chem. Phys., 14, 2669-2678, doi:10.5194/acp-14-2669-2014, 2014.

Liu, Q., Schurter, L. M., Muller, C. E., Aloisio, S., Francisco, J. S., and Margerum, D. W.: Kinetics and mechanisms of aqueous ozone reactions with bromide, sulfite, hydrogen 
sulfite, iodide, and nitrite ions, Inorg. Chem., 40, 4436-4442, doi:10.1021/ic000919j, 2001.

Magi, L., Schweitzer, F., Pallares, C., Cherif, S., Mirabel, P., and George, C.: Investigation of the uptake rate of ozone and methyl hydroperoxide by water surfaces, J. Phys. Chem. A, 101, 49434949, 1997.

Mahajan, A. S., Plane, J. M. C., Oetjen, H., Mendes, L., Saunders, R. W., Saiz-Lopez, A., Jones, C. E., Carpenter, L. J., and McFiggans, G. B.: Measurement and modelling of tropospheric reactive halogen species over the tropical Atlantic Ocean, Atmos. Chem. Phys., 10, 4611-4624, doi:10.5194/acp-10-4611-2010, 2010.

Mahajan, A. S., Gómez Martín, J. C., Hay, T. D., Royer, S.-J., Yvon-Lewis, S., Liu, Y., Hu, L., Prados-Roman, C., Ordóñez, C., Plane, J. M. C., and Saiz-Lopez, A.: Latitudinal distribution of reactive iodine in the Eastern Pacific and its link to open ocean sources, Atmos. Chem. Phys., 12, 11609-11617, doi:10.5194/acp-12-11609-2012, 2012.

Martino, M., Mills, G. P., Woeltjen, J., and Liss, P. S.: A new source of volatile organoiodine compounds in surface seawater, Geophys. Res. Lett., 36, L01609, doi:10.1029/2008g1036334, 2009.

McTaggart, A. R., Butler, E. C. V., Haddad, P. R., and Middleton, J. H.: Iodide and iodate concentrations in eastern Australian subtropical waters, with iodide by ion chromatography, Mar. Chem., 47, 159-172, doi:10.1016/0304-4203(94)90106-6, 1994.

Nakayama, E., Kimoto, T., Isshiki, K., Sohrin, Y., and Okazaki, S.: Determination and distribution of iodide- and total-iodine in the North Pacific Ocean - by using a new automated electrochemical method, Mar. Chem., 27, 105-116, doi:10.1016/03044203(89)90030-3, 1989.

O’Dowd, C. D., Jimenez, J. L., Bahreini, R., Flagan, R. C., Seinfeld, J. H., Hameri, K., Pirjola, L., Kulmala, M., Jennings, S. G., and Hoffmann, T.: Marine aerosol formation from biogenic iodine emissions, Nature, 417, 632-636, 2002.

Oetjen, H.: Measurements of halogen oxides by scattered sunlight differential optical absorption spectroscopy, PhD, Institut für Umweltphysik, Bremen, Germany, Bremen, 2009.

Read, K. A., Mahajan, A. S., Carpenter, L. J., Evans, M. J., Faria, B. V. E., Heard, D. E., Hopkins, J. R., Lee, J. D., Moller, S. J., Lewis, A. C., Mendes, L., McQuaid, J. B., Oetjen, H., Saiz-Lopez, A., Pilling, M. J., and Plane, J. M. C.: Extensive halogen-mediated ozone destruction over the tropical Atlantic Ocean, Nature, 453, 1232-1235, 2008.

Reeser, D. I. and Donaldson, D. J.: Influence of water surface properties on the heterogeneous reaction between $\mathrm{O} 3(\mathrm{~g})$ and $\mathrm{I}-(\mathrm{aq})$, Atmos. Environ., 45, 6116-6120, 2011.

Rouvière, A. and Ammann, M.: The effect of fatty acid surfactants on the uptake of ozone to aqueous halogenide particles, Atmos. Chem. Phys., 10, 11489-11500, doi:10.5194/acp-1011489-2010, 2010.
Rowley, D., Mössinger, J., Cox, R. A., and Jones, R.: The UV-Visible Absorption Cross-Sections and Atmospheric Photolysis Rate of HOI, J. Atmos. Chem., 34, 137-151, doi:10.1023/a:1006210322389, 1999.

Rutgersson, A., Smedman, A., and Sahlée, E.: Oceanic convective mixing and the impact on air-sea gas transfer velocity, Geophys. Res. Lett., 38, L02602, doi:10.1029/2010g1045581, 2011.

Saiz-Lopez, A. and Plane, J. M. C.: Novel iodine chemistry in the marine boundary layer, Geophys. Res. Lett., 31, L04112, doi:10.1029/2003GL019215, 2004.

Saiz-Lopez, A., Saunders, R. W., Joseph, D. M., Ashworth, S. H., and Plane, J. M. C.: Absolute absorption cross-section and photolysis rate of $\mathrm{I}_{2}$, Atmos. Chem. Phys., 4, 1443-1450, doi:10.5194/acp-4-1443-2004, 2004.

Saiz-Lopez, A., Plane, J. M. C., Mahajan, A. S., Anderson, P. S., Bauguitte, S. J.-B., Jones, A. E., Roscoe, H. K., Salmon, R. A., Bloss, W. J., Lee, J. D., and Heard, D. E.: On the vertical distribution of boundary layer halogens over coastal Antarctica: implications for $\mathrm{O}_{3}, \mathrm{HO}_{\mathrm{x}}, \mathrm{NO}_{\mathrm{x}}$ and the $\mathrm{Hg}$ lifetime, Atmos. Chem. Phys., 8, 887-900, doi:10.5194/acp-8-887-2008, 2008.

Saiz-Lopez, A., Plane, J. M. C., Baker, A., Carpenter, L., von Glasow, R., Gómez Martín, J. C., McFiggans, G., and Saunders, R.: Atmospheric chemistry of iodine, Chem. Rev., 112, 17731804, 2012.

Saunders, R. W., Mahajan, A. S., Gómez Martín, J. C., Kumar, R., and Plane, J. M. C.: Studies of the Formation and Growth of Aerosol from Molecular Iodine Precursor, Zeitschrift fuer Physikalische Chemie (Munich), 224, 1095-1117, 2010.

Shaw, M. D. and Carpenter, L. J.: Modification of Ozone Deposition and I2 Emissions at the Air-Aqueous Interface by Dissolved Organic Carbon of Marine Origin, Environ. Sci. Technol., 47, 10947-10954, doi:10.1021/es4011459, 2013.

Truesdale, V. W., Bale, A. J., and Woodward, E. M. S.: The meridional distribution of dissolved iodine in near-surface waters of the Atlantic Ocean, Prog. Oceanogr., 45, 387-400, doi:10.1016/S0079-6611(00)00009-4, 2000.

Tsunogai, S. and Henmi, T.: Iodine in the surface water of the ocean, J. Oceanogr. Soc. Jpn., 27, 67-72, doi:10.1007/bf02109332, 1971.

Weishaar, J. L., Aiken, G. R., Bergamaschi, B. A., Fram, M. S., Fujii, R., and Mopper, K.: Evaluation of Specific Ultraviolet Absorbance as an Indicator of the Chemical Composition and Reactivity of Dissolved Organic Carbon, Environ. Sci. Technol., 37, 4702-4708, doi:10.1021/es030360x, 2003.

Woittiez, J. R. W., van der Sloot, H. A., Wals, G. D., Nieuwendijk, B. J. T., and Zonderhuis, J.: The determination of iodide, iodate, total inorganic iodine and charcoal-adsorbable iodine in seawater, Mar. Chem., 34, 247-259, doi:10.1016/03044203(91)90006-I, 1991. 